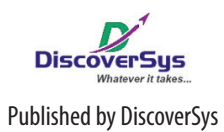

Published by DiscoverSys

\section{The effectiveness of WhatsApp video to increase knowledge of pneumonia early detection among mothers of children under five years}

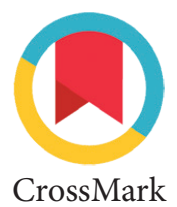

Ni Wayan Erviana Puspita Dewi, ${ }^{1 *}$ Anak Agung Sagung Sawitri, ${ }^{2}$ Partha Muliawan ${ }^{2}$

\title{
ABSTRACT
}

Background and purpose: Number of people in Indonesia who have access to smartphones is quite high, but their use for health education media specifically for the detection of pneumonia is still limited. This study aims to determine the effectiveness of use of video information through the WhatsApp (WA) application compared to leaflets in order to increase maternal knowledge about early detection of pneumonia among under-five children.

Methods: A pretest-posttest randomized control trial was conducted in three of the six sub-villages (called banjar) in the Gelgel Village, Klungkung District. Banjar was selected purposively by considering the distance between banjar. As many as 30 mothers were selected as samples from around 45-50 mothers of children under five in each banjar. The intervention was conducted randomly where one banjar was given intervention with videos through WA, one banjar with leaflets and one banjar as a control group. The intervention was carried out for three weeks (August-September, 2018). Data were collected before and after the intervention through face-to-face interviews with the mothers in their homes, which included social demographics, mother's knowledge about pneumonia detection and educational media preferences. Bivariate data analysis was conducted with paired t-test and multivariate analysis with General Linear Model.

Results: Characteristics of respondents in all three groups were similar in terms of age, education, employment, and parity. The results of interviews on educational media choices showed that most respondents (64\%) preferred WA media. The increase in mean knowledge score after the intervention was significantly higher in the WA group which was 6.93 (95\% Cl: 6.38-7.49) and leaflet 5.90 (95\%Cl: 5.49-6.44) compared to the control group 1.87 (95\% Cl: 1.26-2.47). There was no significant difference between the WA and the leaflet group. The results of multivariate analysis showed that educational media $(F=110.99 ; p<0.01)$ and education $(F=16.69 ; p<0.01)$ were significantly associated with the increase in knowledge after adjustments were made based on age, employment and parity. Conclusion: WA videos and leaflet were found to be effective in increasing maternal knowledge about early detection of pneumonia in under-five children. Because the use of WA application is increasing, efforts to improve health knowledge with WA videos need to be enhanced.

Keywords: media of education, knowledge, pneumonia, WhatsApp, leaflets

Cite This Article: Dewi, N.W.E.P., Sawitri, A.A.S., Muliawan, P. 2019. The effectiveness of WhatsApp video to increase knowledge of pneumonia early detection among mothers of children under five years. Public Health and Preventive Medicine Archive 7(1):60-65. D0l:10.15562/phpma.v7i1.201

'Public Health Postgraduate Program, Faculty of Medicine, Udayana University,

${ }^{2}$ Department of Public Health and Preventive Medicine, Faculty of Medicine, Udayana University
*Correspondence to:

Ni Wayan Erviana Puspita Dewi,

Public Health Postgraduate Program, Faculty of Medicine, Udayana

University

ervicabi@gmail.com

\section{INTRODUCTION}

Indonesia ranks the second largest internet users in the world with more than $69 \%$ of Indonesians access the internet using mobile devices. ${ }^{1}$ This figure is higher than the internet usage via mobile globally, which is $50 \%$. $^{1}$ The most widely used social media platform for the Indonesian people is Youtube (43\%), Facebook (41\%) and WA (40\%). These forms of social media have not been widely used in health programs as a means of disseminating health information to the public. A survey conducted by the Indonesian Internet Service Provider Association or Asosiasi Penyelenggara Jasa Internet Indonesia (APJII) showed that only $21.7 \%$ of internet users used the facility to send videos for education and $49.7 \%$ used the internet to view video tutorials. ${ }^{2}$

Information that distributed through social media has several advantages, including ability to be distributed by the maker and can be seen at any time by the user without being too disruptive to both parties. Media shared through WA is one of the communication media capable of delivering health information and has several advantages, including having features to send images, videos, sounds, and text messages for free depending on internet connection. Therefore WA can be used to distribute audiovisual health promotion media that has higher coverage and speed than conventional media. ${ }^{3}$ Whereas leaflets, which are one of the conventional media, have several advantages that they can be stored for a long time, if forgotten can be reopened, if necessary can be used for discussion material for different occasions and so forth. Leaflets have some weaknesses; for example, people are reluctant to save if the appearance is less attractive, they can be difficult to read if the letters are too small and cannot be used by illiterate people. ${ }^{4}$ 
Pneumonia remains the highest cause of death $(16 \%)$ in children worldwide, higher than deaths caused by diarrhea, sepsis, malaria, tuberculosis and HIV\&AIDS. ${ }^{5}$ Pnemumonia in Indonesia is the second leading cause of deaths in children under five years after diarrhea. ${ }^{6}$ In 2015, the Klungkung District occupied the highest position in terms of pneumonia case finding among children under five years, ${ }^{7}$ and in 2016 was the third in nine districts/ cities in Bali Province. ${ }^{8}$ The provision of information for health promotion in Klungkung District still uses conventional methods in forms of faceto-face counseling, incidental, and limited coverage so they cannot reach the audience on a wider scale. Some studies show that maternal knowledge, delay in treatment and in accessing health services are severe pneumonia risk factors, ${ }^{9-11}$ therefore, maternal knowledge is a factor that must be considered to improve the efforts of mothers to carry out early detection. Several other studies have shown that educational media with flipcharts and booklets can increase knowledge about health, especially pneumonia in children under five years. ${ }^{12-17}$

Published studies on the use of WA for the promotion of early detection of pneumonia in health programs in Indonesia is still limited. This study aims to determine the effectiveness of WA videos as an educational media in increasing maternal knowledge about early detection of pneumonia in under-five children compared to leaflets as conventional media.

\section{METHODS}

A pretest-posttest randomized control trial was conducted with 90 mothers of children underfive residing in one of the villages closest to the Klungkung I Public Health Center, namely in Gelgel Village, Klungkung Sub-district, Klungkung District, Bali Province. In this village there were six banjar, and three banjar were chosen as the study locations with a considerable distance from each other, namely one banjar in the west, one banjar in the centre and one banjar in the eastern part of the village. Selected mothers in one banjar were given intervention with WA videos, one banjar with leaflets and one banjar as a control. Random allocation of WA, leaflets and control was employed in the three banjar. Video through WA and leaflets given to mothers who had children under five. The number of all mothers of children under five in each banjar ranged from 45-50 people. The minimum sample needed was 30 mothers for each group (a total of 90 under-five mothers). The number of samples was calculated with a confidence level of $95 \%$, power of $80 \%$, mean knowledge of upper respiratory tract infection before intervention of 6.8 and mean knowledge after intervention of $8.16 .{ }^{18}$ Eligible subjects were mothers who had children under five, educated at least elementary school, used Android phones, reported frequent use of the WA application and were willing to take part in the study. The samples were selected until it reached 30 mothers for each group consecutively.

Interventions in this study were video education media or leaflets. Researchers designed educational media in the form of video by referring to the Integrated Management of Childhood Illnesses or Manajemen Terpadu Balita Sakit (MTBS) from the Indonesian Ministry of Health ${ }^{19}$ and documents issued by the Indonesian Pediatric Association or Ikatan Dokter Anak Indonesia (IDAI). ${ }^{20}$ The video was a two minute animated cartoon with material covering definitions of pneumonia, signs and symptoms, rapid breath classification according to the age of the under-five children and how to calculate fast breathing. The distributed media leaflets were paper-based consisted of writings and images with the same substance as the video. Data collection before and after the intervention was carried out through face-to-face interviews in each respondent's house using a questionnaire covering sociodemographic characteristics (age, education, employment and parity), knowledge of early pneumonia detection following video content and leaflets. After the intervention, data on media evaluation and respondents' preferences for media intervention also collected. Questions about knowledge consisted of 15 items. Each item was given a score of one for the correct answer and a score of zero for the incorrect one so that the maximum score of the correct answer for knowledge is 15. Evaluation questions consisted of four items, and preferences question consisted of one item.

Data collection of pretest-posttest was carried out by researchers assisted by enumerators who had been trained beforehand. During the home visits before the intervention, the researcher explained the objectives, benefits, time, and study implementation for the selected mothers. After they agreed to participate in the study and listed the telephone number on the consent sheet, they interviewed with a pre-intervention questionnaire for approximately ten minutes. Afterward, in the WA group, researchers sent videos through the WA application to the mothers at the end of the first week, and the video was resent every weekend for three weeks. The researcher monitored every end of the week regarding whether WA has been opened or not with a blue check indicator, read or not by asking through WA and recording the response. Whereas in the leaflet group, after being interviewed with the pretest questionnaire, leaflets were immediately given in the first week. 
In this group, leaflets were not repeatedly distributed and no monitoring was carried out. In the control group, after pretest interviews, WA and leaflets were not disseminated and this is in accordance with the public health center standards. The duration of the intervention was three weeks. On the second visit, at the end of the third week, researchers conducted post-intervention evaluations. After the mothers finished answering all questions about knowledge, those in the WA and leaflet groups were given an evaluation questionnaire about the media obtained by each group. After they finished answering the evaluation questions, the researchers showed the leaflets to the WA group, videos shown to the leaflet groups, and both videos and leaflets shared with the control group. Researchers then gave a preference questionnaire which assessed the more preferred media by the mothers.

Data were analyzed descriptively for variables of knowledge, age, education, employment and parity. The normality test showed that data of knowledge was normally distributed, so that parametric analysis was performed. Paired t-tests were conducted to determine the mean differences in knowledge scores before and after the intervention in each group. Covarian analysis (ANCOVA) was employed to determine the role of media, maternal socio-demographic characteristics and increasing knowledge. Post-hoc analysis was carried out to find the group that had the most significant differences between the three groups towards increasing maternal knowledge. This study has been approved by the Ethics Committee of the Faculty of Medicine, Udayana University/Sanglah Hospital on August 6, 2018.

\section{RESULTS}

A total of 90 mothers participated in this study. Characteristics of mothers are presented in Table 1. There was no significant differences in the social demographic characteristics between the WA, leaflet and control group.

A normality test with Kolmogorov-Smirnov was conducted to determine the normality of data distribution in each group, and it was found that mothers' knowledge was normally distributed, in each group of WA $(\mathrm{p}=0.09)$, leaflets $(\mathrm{p}=0.06)$ and control $(\mathrm{p}=0.19)$.

Table 2 shows that there was a difference in the average of mothers' knowledge score in each group before and after the intervention. There is no significant difference in the average scores of knowledge before intervention in the three groups. Mothers in the three groups were able to answer about six of the fifteen questions. After the intervention, there was a significant increase in the mean score of knowledge $(\mathrm{p}<0.01)$ in the three groups, where the highest post test score was in the WA group. The difference in pre-test and posttest mean scores of knowledge in WA group was 6.93 points, leaflet group was 5.97 and control group was 1.87 .

Table 3 presents the results of multivariate analysis with ANCOVA to determine the role of media and maternal socio-demographic characteristics towards knowledge. It can be seen that media and mother's education level were significantly associated with knowledge with $\mathrm{F}=110.99(\mathrm{p}<0.01)$ and the level of education with $\mathrm{F}=16.69(\mathrm{p}<0.01)$, while age, occupation and parity were not associated with knowledge.

In Table 4, the results of ANCOVA (post-hoc) are presented to find out which group had the most significant differences between the three groups. It appears that the mean difference between the WA and control groups was 4.72 (95\%CI: 3.89-5.56; $\mathrm{p}<0.01$ ), the leaflet and control groups was 3.97 (95\%CI: 3.15-4.79; $\mathrm{p}<0.01$ ), while the WA and leaflet groups was 0.75 (95\% CI: $-0.05-1.57 ; \mathrm{p}=0.08$ ).

The evaluation of media preferences showed that $64.4 \%$ of mothers stated that they preferred video media through the WA application because

Table 1 Characteristics of mothers in the WA, leaflets and control group

\begin{tabular}{|c|c|c|c|c|c|c|c|}
\hline Characteristics & \multicolumn{2}{|c|}{ WA $(n=30)$} & \multicolumn{2}{|c|}{ Leaflet $(n=30)$} & \multicolumn{2}{|c|}{ Control $(n=30)$} & $\mathbf{p}$ \\
\hline Age (years)* & \multicolumn{2}{|c|}{$28.6 \pm 3.1$} & \multicolumn{2}{|c|}{$28.6 \pm 3.7$} & \multicolumn{2}{|c|}{$27.9 \pm 3.2$} & 0.874 \\
\hline \multicolumn{8}{|l|}{ Education $^{\star *}$} \\
\hline $\begin{array}{l}\text { Elementary-junior } \\
\text { high }\end{array}$ & 4 & $(13.3)$ & 8 & (26.7) & 8 & $(26.7)$ & 0.358 \\
\hline Senior high-tertiary & 26 & $(86.7)$ & 22 & $(73.3)$ & 22 & (73.3) & \\
\hline \multicolumn{8}{|l|}{ Employment** } \\
\hline Employed & 19 & $(63.3)$ & 17 & $(56.7)$ & 18 & $(60.0)$ & 0.954 \\
\hline Unemployed & 11 & (36.7) & 13 & (43.3) & 12 & $(40.0)$ & \\
\hline Parity* & \multicolumn{2}{|c|}{$1.9 \pm 0.8$} & \multicolumn{2}{|c|}{$2.0 \pm 0.7$} & \multicolumn{2}{|c|}{$1.8 \pm 0.8$} & 0.605 \\
\hline
\end{tabular}

${ }^{\star}$ One Way Anova; ${ }^{*}$ Chi square test 
Table 2 Mean differences of knowledge score in each group before and after the intervention

\begin{tabular}{|c|c|c|c|c|c|c|c|}
\hline \multirow[b]{2}{*}{ Groups } & \multirow{2}{*}{$\begin{array}{l}\text { Pre } \\
\text { Test }\end{array}$} & \multirow{2}{*}{$\begin{array}{l}\text { Post } \\
\text { Test }\end{array}$} & \multirow[b]{2}{*}{ Mean } & \multirow[b]{2}{*}{ SD } & \multicolumn{2}{|c|}{$95 \% \mathrm{Cl}$} & \multirow[b]{2}{*}{$\mathbf{p}$} \\
\hline & & & & & Lower & Upper & \\
\hline WA & 5.90 & 12.83 & 6.93 & 1.48 & 6.38 & 7.49 & $<0.01$ \\
\hline Leaflet & 5.97 & 11.93 & 5.90 & 1.27 & 5.49 & 6.44 & $<0.01$ \\
\hline Control & 6.43 & 8.30 & 1.87 & 1.61 & 1.26 & 2.47 & $<0.01$ \\
\hline
\end{tabular}

${ }^{*}$ Paired t-test

Table 3 F values of media, age, education, employment and parity

\begin{tabular}{lcc}
\hline Variables & $\mathbf{F}$ & $\mathbf{p}$ \\
\hline Media & 110.99 & $<0.01$ \\
Age & 0.01 & 0.91 \\
Education & 16.69 & $<0.01$ \\
Employment & 0.02 & 0.89 \\
Parity & 0.39 & 0.53 \\
\hline
\end{tabular}

Table 4 Mean differences of knowledge score between groups before and after intervention

\begin{tabular}{lcccc}
\hline Methods & Mean & & $\mathbf{9 5 \% C l}$ & p \\
\hline WA versus control & 4.72 & 3.89 & 5.56 & $<0.01$ \\
Leaflet versus control & 3.97 & 3.15 & 4.79 & $<0.01$ \\
WA versus leaflet & 0.75 & 0.05 & 1.57 & 0.08 \\
\hline
\end{tabular}

it can be easily stored, more interesting, readable and practical, while as many as $35.6 \%$ chose leaflet media because the leaflets could be read in a long time and don't require access to internet.

\section{DISCUSSION}

Our study shows that education using video media through WA applications or usingleaflets significantly increases mothers' knowledge about early detection of pneumonia in children under five compared to the control group. The difference in the average score of knowledge in pretest and posttest in the WA group was higher than that of the leaflet group but was not statistically significant. Multivariate analysis showed that WA and leaflets significantly increased the level of knowledge compared to the control group. Although the mean difference in the WA group and leaflet group was almost the same, the video media through the WA application increased knowledge more in terms of practice about fast breath classification and rapid breathing counting method for early detection of pneumonia in infants (data not shown). In addition, evaluations at the end of the third week also showed that respondents preferred video media through WA, while respondents who received leaflets reported that leaflets were only read one to two times and mostly reported that leaflets had been lost and damaged.

The advantage of video through the WA application is probably related to the presence of stimulus via aural and visual modes so that more effective than leaflets which only provided a visual stimulus. ${ }^{3}$ A study in Wonokerto Village, Yogyakarta about health promotion through educational images using WA application disseminated by cadres found that WA was an effective media for education program on type 2 diabetes. ${ }^{16}$ The effectiveness of video as an education media for signs, symptoms and how to seek treatment for children under five years was also reported in a study in North India. ${ }^{14}$ A randomized controlled trial showed that after group discussions and reminders via WA, it is effective to prevent smoking relapse in subjects who had quit smoking. ${ }^{21}$ In addition, WA proved to be effective in improving physical fitness thus decreasing the cardiovascular disease risk factor; although less effective compared to face-to-face consultation. ${ }^{22}$ Some studies also show that video media is effective in increasing public knowledge about health behavior and the use of WA as a mobile learning is reported to be effective in the learning process to improve critical thinking skills. ${ }^{23,24}$ Although the majority of studies reported that video is more 
effective, a study in Kalimantan about the dangers of smoking showed that leaflets were more effective in increasing adolescent knowledge than video. ${ }^{15}$

In our study, other than educational media, respondent's education also significantly affected the increase in mother's knowledge about early detection of pneumonia in children under five years, while work, age, and parity did not effect increasing maternal knowledge. This is similar to a study conducted in Surakarta suggesting that education affects mother's knowledge of acute respiratory infection while work, age, and parity do not. ${ }^{25}$

Educational media preferences in our study show that most (64.4\%) of mothers chose video media through the WA application because it can be easily stored, more interesting, can be read at any time and were more practical, while the number of respondents who chose leaflets was less (35.6\%). Respondents who chose leaflets stated that the advantages of leaflets compared to videos were that they could be read repeatedly and did not require the internet. In the post-intervention evaluation, however, the majority of respondents mentioned that leaflets were only read one to two times and the leaflets were lost and damaged. The results of our study indicate that there is a high opportunity for WA videos in community education in Indonesia. In addition, the use of WA in Indonesia is ranked third (40\%) after YouTube and Facebook; and WA has advantages in video delivery, has wider features and functions. ${ }^{1}$

The limitation of this study was banjar were selected only from one village. Although the distance between the selected banjar was rather far apart, there was the possibility of interaction and exchange of information between respondents. Another possible weakness was the relatively short time interval between the pre test and post test (3 weeks), so the respondents were likely to still remember the questions given at the time of the pretest.

\section{CONCLUSION}

WA videos and leaflets were found to be effective in increasing maternal knowledge about early detection of pneumonia in under-five children. However, WA video is more desirable in delivering health information than leaflets. Because the use of WA application is increasing, efforts to increase health knowledge with WA videos need to be enhanced.

\section{ACKNOWLEDGEMENT}

We would like to thank all respondents, the head of the Klungkung I Public Health Center and village midwives who have facilitated the implementation of this study.

\section{REFERENCES}

1. Globalwebindex. Welcome to the audience era: the trends to watch 2017 [serial online]. 2017. Available at: https:// globalwebindex.com [cited 2018 September 30].

2. Indonesian Internet Service Provider Association. Pemanfaatan internet bidang edukasi: penetrasi \& perilaku pengguna internet Indonesia [Internet use for education: behaviors of Indonesian internet users] [serial online]. 2017. Available at: https://www.apjii.or.id [cited 2018 September 30].

3. Notoatmodjo S. Promosi kesehatan dan ilmu perilaku [Health promotion and behavioral sciences]. Jakarta: Rineka Cipta. 2007.

4. Simamora. Media pembelajaran: Buku ajar pendidikan dalam keperawatan [Teaching media: Teaching book of nursing education]. Cetakan Pertama. Jakarta: EGC. 2009.

5. UNICEF. Pneumonia the deadliest childhood disease. New York. 2015. Available at: https://data.unicef.org.

6. Ministry of Health of Indonesia. Profil Kesehatan Indonesia Tahun 2016. [The 2016 Indonesia Health Profile]. Jakarta: Ministry of Health of Indonesia. 2016

7. Bali Province Health Office. Profil Kesehatan Provinsi Bali Tahun 2015. [The 2015 Indonesia Health Profile]. Denpasar: Bali Province Health Office. 2015

8. Bali Province Health Office. Profil Kesehatan Provinsi Bali Tahun 2016. [The 2016 Indonesia Health Profile]. Denpasar: Bali Province Health Office. 2016

9. Mokoginta D, Arsin A, Sidik D. Faktor risiko kejadian pnemonia pada anak balita di wilayah kerja Puskesmas Sudiang Kota Makassar (thesis) [Risk factors of pneumonia among under five years children in the working area of Sudiang Public Health Center Makassar City (thesis)]. 2013. Universitas Hasanuddin.

10. Rahim R. Hubungan pengetahuan dan sikap ibu balita dengan pencegahan penyakit pneumonia di wilayah kerja Puskesmas Putri Ayu Tahun 2013 [The association of knowledge and attitude of mothers of under five years children towards pneumonia in the working area of Putri Ayu Public Health Center 2013]. The Jambi Medical Journal. 2013; 1(1): 1-13

11. Abadi DAKS, Wirawan DN, Sawitri AAS, Windiani GAT. Delayed access to treatment and frequency of acute respiratory infection as risk factors of severe pneumonia among children aged 12-59 months in Denpasar, Bali. Public Health and Preventive Medicine Archive. 2017; 5(1): 76-82

12. Pamurti S. Efektivitas pendidikan kesehatan dengan media kalender oleh kader posyandu dalam meningkatkan kemampuan ibu mendeteksi dini pneumonia balita [Effectiveness of health education using a media of calender by the cadres of health integrated post in increasing the ability of mothers in early detection of pneumonia among under five years children]. Journal of Health Education. 2016: 1(2); 8-16.

13. Fauziah AN, Maesaroh S, Sulistyorini E. Penggunaan leaflet terhadap peningkatan pengetahuan tentang pemeriksaan payudara sendiri [The use of leaflets and the increase of knowledge on self breast examination]. Jurnal Ilmu Kesehatan. 2017;14(2).

14. Awasthi S, Verma T, Agarwal M. Developing effective health communication messages for community acquired pneumonia in children under five years of age: A rural North Indian qualitative study. Jurnal Clinical Epidemiology and Global Health. 2017; 5(3): 107-116.

15. Persada KB, Kasman, Nordiyah. Studi eksperimen penggunaan media leaflet dan video [An experimental study on the use of leaflet and video]. Jurnal Publikasi Kesehatan Masyarakat Indonesia. 2017; 4(2): 10-14.

16. Ekadinata N, Widyandana D. Promosi kesehatan menggunakan gambar dan teks dalam Aplikasi Whatsapp pada kader posbindu [Health promotion using picture and texts in Whatsapp application among cadres]. Jurnal of Community Medicine and Public Health. 2017; 2(2): 1123-1130. 
17. Saraswati K, Sugiyono. Pengaruh pemberian edukasi stimulus visual melalui WA (Whatsapp Messenger) terhadap motivasi berhenti merokok mahasiswa Teknik Mesin Universitas Muhammadiyah Yogyakarta Angkatan 2014 (Tesis) [The influence of visual education through Whatsapp Messenger towards motivation to stop smoking among engineering students Muhammadiyah University Yogyakarta (Thesis)]. 2014. Yogyakarta: Universitas Muhammadiyah Yogyakarta.

18. Fauzi FM. Analisis faktor-faktor yang berpengaruh terhadap perawatan ISPA pada balita [Analysis of factors that influence the management of acute respiratory infection among under five years children]. Gaster: Jurnal Kesehatan. 2018;16(1): 49-63.

19. Ministry of Health of Indonesia. Manajemen Terpadu Balita Sakit (MTBS) [The integrated diseases management among under five years children]. 2015; Jakarta: Ministry of Health of Indonesia.

20. Indonesia Pediatrician Association. Hitung napas anak deteksi awal sesak napas pada anak dengan pneumonia [Counting children's respiration as an early detection of breathing difficulty among children with pneumonia]. [serial online] 2017 September 06 [cited 2018 Pebruari 04] Available at: http://www.idai.or.id.

21. Cheung, Y.T;Chan, C.H;Lai, C.K.;Chan, W.F.;Wang, M.P.;Li, H.C.;Chan, S.S.; Lam T. Using WhatsApp and Facebook online social groups for smoking relapse prevention for recent quitters_a pilot pragmatic cluster randomized controlled trial. Journal of Medical Internet Research. 2015;17(10):e238
22. Muntaner-Mas A, Vidal-Conti J, Borras PA, Ortega FB, Palou P. Effects of a WhatsApp-delivered physical activity intervention to enhance health-related physical fitness components and cardiovascular disease risk factors in older adults. The Journal of Sports Medicine and Physical Fitness. 2017;57(1-2):90-102.

23. Agni RM, Sri E. Pengembangan video penyuluhan perilaku hidup bersih dan sehat (PHBS) bermuatan nilai karakter terhadap peningkatan pengetahuan masyarakat dalam menanggulangi penyakit diare [Development of video education on healthy and hygiene behaviors towards the increase of community knowledge in diarrhea control]. Jurnal Pendidikan. 2017;2(7):883-8.

24. Kartikawati S, Pratama H. Pengaruh penggunaan WhatsApp Messenger sebagai mobile learning terintegrasi metode group investigation terhadap kemampuan berpikir kritis [The influence of WhatsApp Messenger as a mobile learning integrated with group investigation method towards critical thinking ability]. JUPITER (Jurnal Pendidikan Teknik Elektro). 2017;2(2):33-8.

25. Wea KB. Pendidikan kesehatan dengan media audiovisual Kabupaten Ngada [Health education with audiovisual media Ngada District]. 2014. 55-61.

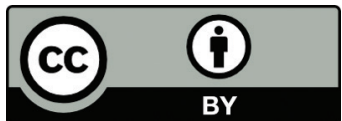

This work is licensed under a Creative Commons Attribution 